\title{
6 Climate change, gendered vulnerabilities and resilience in high mountain communities
}

\author{
The case of Upper Rasuwa in Gandaki \\ River Basin, Hindu Kush Himalayas
}

\section{Deepak Dorje Tamang and Pranita Bhushan Udas}

\section{Introduction}

There is growing recognition of the need for context-specific understanding of gendered vulnerabilities to address issues of climate change and consequent socio-economic changes (Goodrich et al. 2019a). Mountains are climate 'hot spots' (Khan et al. 2018), and communities living in rugged and difficult mountain terrain are more vulnerable to climate change than those living in the plains (Sharma et al. 2019). Mountain people contribute significantly to the lives of downstream populations by providing, among other things, rare high-value medicinal resources. Yet their wellbeing indicators show how vulnerable they are to a changing climate (Gerlitz et al. 2011; Humagain and Shrestha 2009). Basic facilities like water, energy, health care and education are scarce in the high mountains. Limited public services provided by the government are difficult to access due to lack of capabilities (Pasteur 2011). Climatic stressors have further increased the vulnerabilities of the mountain communities and intensified existing disparities. Understanding and responding to their vulnerabilities is crucial not only for climate change adaptation initiatives but also for achievement of the Sustainable Development Goals.

This chapter examines gendered vulnerabilities in the high mountain villages of the upper Rasuwa district of Nepal. ${ }^{1}$ This is part of a region popularly known as the Hindu Kush Himalayas. People living in the district are witnessing the changing climate and its impact on their day-to-day lives (Campbell 2017). The study seeks to understand people's livelihoods in the context of climate change in a scenario of high social and gender differentiation. In this chapter, we examine how people belonging to different genders, castes, classes, ethnic, education and age groups are coping with the changes. This analysis is expected to contribute to gender-sensitive adaptation planning for the high mountain regions of Nepal.

The chapter is organized in six sections. Following this introduction, we discuss research methodology and introduce the study villages. Section three 
conceptualizes and highlights gendered vulnerability in the high mountain regions. In the fourth section we analyze the gender roles and responsibilities across the various livelihood strategies undertaken by differently positioned households. Based on evidence from section four, section five analyzes gender vulnerabilities. The last section presents conclusions from the analysis.

\section{Research methodology and study area}

This chapter is based on a larger study of gendered vulnerabilities in the Nepalese and Indian part of the Gandaki river basin (Figure 6.1) under the Himalayan Adaptation, Water and Resilience (HI-AWARE) research project undertaken by the International Centre for Integrated Mountain Development between 2015 and 2018. ${ }^{2}$ The chapter synthesizes findings from upstream areas of the basin, with cases from Nepal's Rasuwa district, home to about 89,000 people. The study villages are located in the northern part of the district.

The study uses qualitative methods of data collection. Two sets of primary data are analyzed: data collected in 2016 that identifies drivers and conditions of socio-economic vulnerabilities; and data collected in 2017 on gender vulnerabilities. Transect walks, participant observation, key informant interviews, focus group discussions (FGDs) and case studies were used. For the gender vulnerability analysis, 40 FGDs were conducted with homogeneous groups of women and men belonging to similar caste/ ethnic groups, of similar socio-economic status as reflected in their food sufficiency (more than 9 months, up to 6 months and up to 3 months) and using similar livelihood strategies. A semi-structured checklist was used to obtain inter-generational and intersectional information from the respondents.

The mountainous upstream section of the basin has low population density due to the hardships of steep slopes, snow and lower land fertility. The average population density of the upstream districts in Nepal - Mustang, Manang and Rasuwa - is nine persons per square kilometre, compared to 183 and 278 persons per square kilometre respectively in the mid- and downstream districts of the basin (Dandekhya et al. 2017).

Increased temperature and changing precipitation patterns are observed in upstream areas. The HI-AWARE study on 30-year temperature data (1981-2010) show that both maximum and minimum temperatures have increased by nearly $1.55^{\circ} \mathrm{C}$ and $0.0521{ }^{\circ} \mathrm{C}$ in upstream areas in all seasons, with the highest trend in the post-monsoon season (all significant at the 95 per cent confidence level). Annual precipitation has decreased by 59 $\mathrm{mm}$ in the last 30 years, with the winter dry period increasing significantly (HI-AWARE 2017).

Another study on temperature trends, snow cover and river discharge in the upper Gandaki shows that changing climate has an impact on snow 


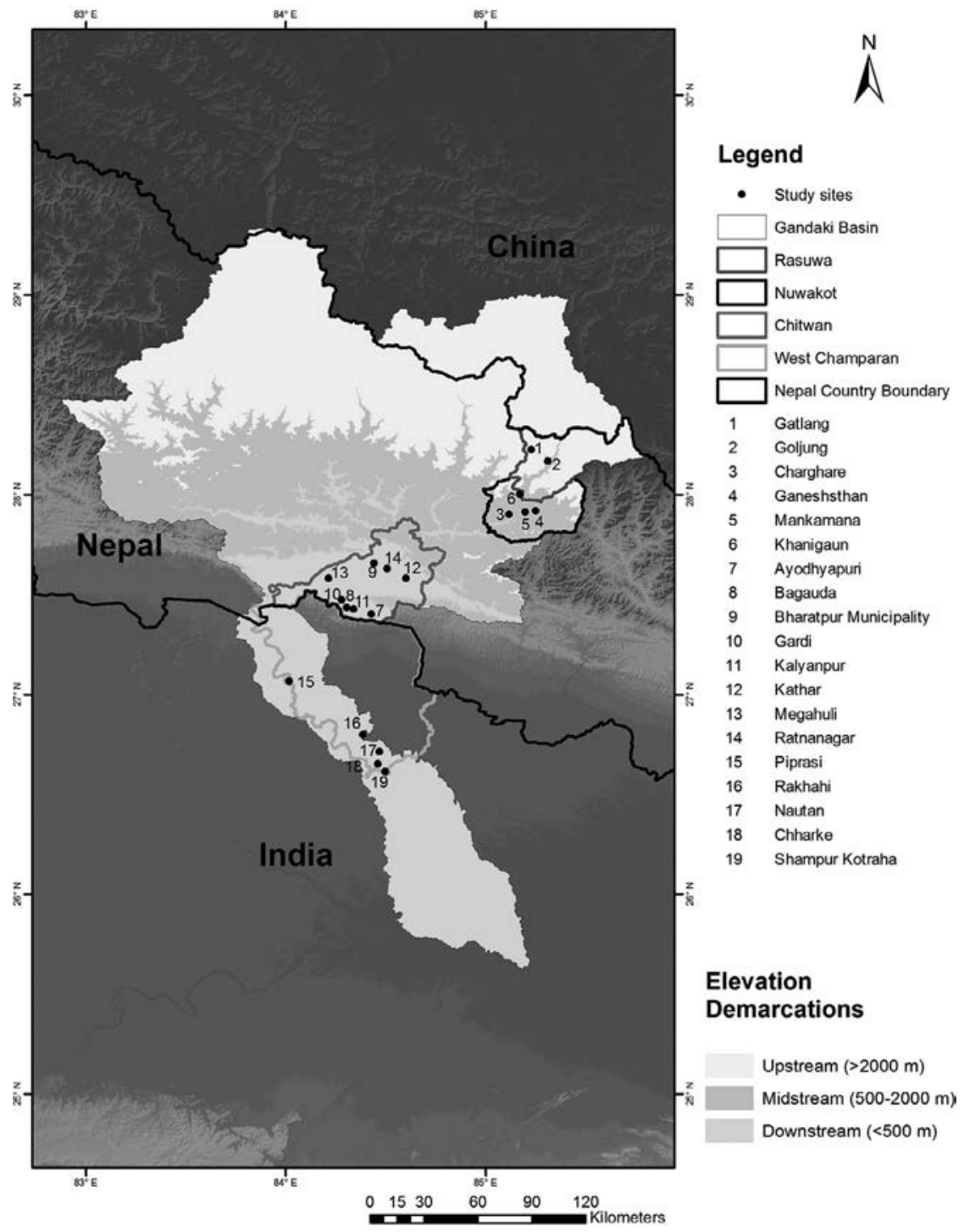

Figure 6.1 Gandaki river basin.

Source: Field study, 2017.

Note: This map does not reflect the political boundaries.

cover. Satellite data showing declining snow coverage between 2003 and 2012, correlated with temperature data between 2000 and 2007 and in-situ river discharge data between 1968 and 2010 indicate a trend towards increased river discharge (Gurung et al. 2017). The implications for farming are that soil moisture retained through annual snow coverage is declining, leading to crops drying prematurely. The farmers say that productivity 
of traditional crops is falling, leading to declining acreages of traditional high-value crops like buckwheat and millet. Between 2001 and 2011, the area under millet in high-altitude areas of Nepal like the upper Rasuwa has declined by 19 per cent, barley by 35 per cent and buckwheat by 40 per cent (CBS 2013). The impact of rising temperature is observed in day-to-day life, with women respondents reporting frequent incidences of nose bleeding among children during summer.

The three study villages in the upper Rasuwa - Gatlang, Goljung and Chilime $^{3}$ - are located along the Trishuli river, a tributary of the Gandaki about 2,000 $\mathrm{m}$ above mean sea level (Figure 6.2). People living in this rugged terrain eke out a living through snow moisture-fed high mountain agriculture and transhumance.

Tamang ethnic groups dominate the population. The second-largest is the Ghale ethnic group and there are a few marginalized Hindu castes of the Dalit group. According to the Village Development Committee data, Gatlang has 508 Tamang households and five Dalit households but no Ghale households. In Goljung, out of 269 households, 60 per cent are Tamang, 39 per cent are Ghale and there are only two Dalit households. In Chilime, out of 340 households, 20 are Ghales and five Dalits. The rest are Tamangs. Tamangs and Ghales are homogeneous non-hierarchical Buddhist groups. They are Tibeto-Burman Mongolian groups and speak a similar tonal language. Historically disadvantaged and discriminated against, neither they nor the Dalits are represented in government institutions or political parties

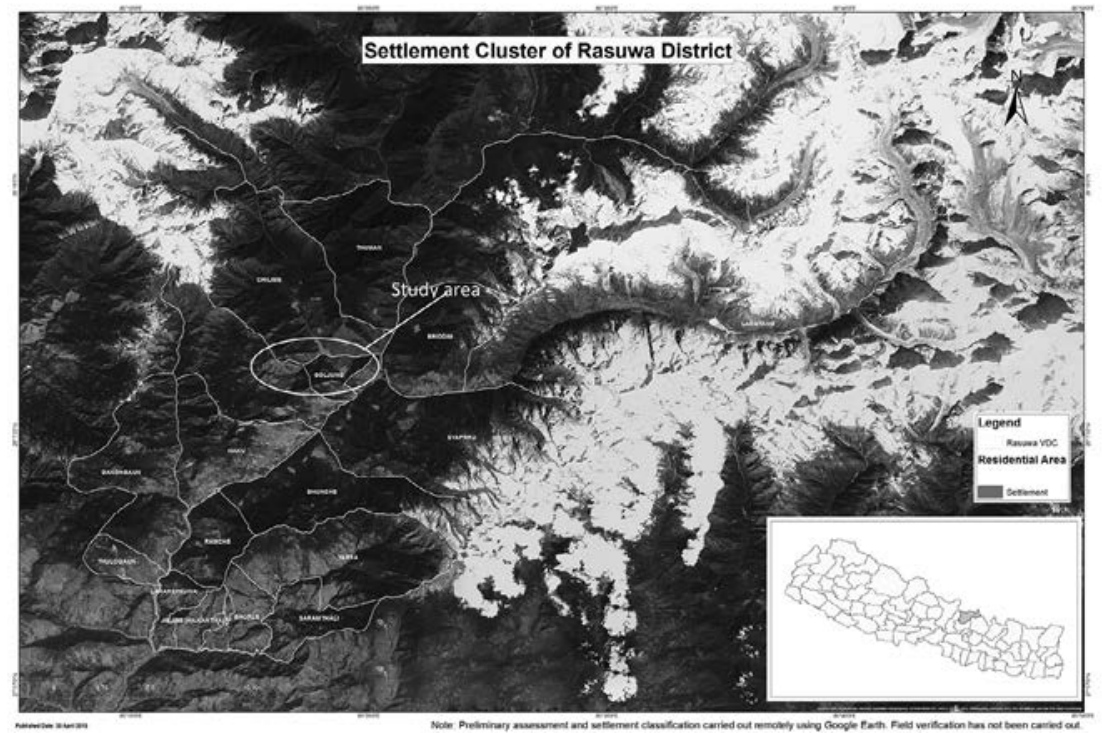

Figure 6.2 Satellite image of study villages in Rasuwa district.

Source: Created by ICIMOD, 2018. 
at the national and provincial level (Tamang and Gurung 2014). According to the Civil Code of 1854, based primarily on Hindu religious and legal texts, the highest caste category is the holy thread wearer Brahmin/Chhetri, followed by the bulk of ethnic groups categorized as non-enslavable, such as Ghale, and enslavable, such as Tamang. At that time, the royal, non-beefeating Ghales were considered as in a higher category than Tamangs. Over time these distinctions have become diluted with intermarriage between Ghale and Tamang (Campbell 1997). Below these is the 'untouchable' or Dalit category (Pradhan and Shrestha 2005). Dalits here are from the iron smith (kami) group. The presence of a few kami in each village was promoted by the state to support the farming community, here composed of Tamang and Ghale, by preparing farm tools in exchange for agricultural produce which ensured their food security. Hence, the Dalits have no farmland, and own only their homestead. A few Tamang and Ghale are large landowners, with holdings up to 0.6 ha., but the majority have on average 0.25 ha. land. Despite positive policies to address this historical social discrimination, Dalits are the most discriminated against, as they fall into the socially 'untouchable' category and lack land resources. Even the dominant Buddhist groups of Ghale and Tamang in the three villages follow historically rooted norms of untouchability.

The three villages differ in types of crop grown due to the differences in altitude, aspect and type of soil. The settlement in Gatlang is above 2,200 m above sea level, in Goljung 1,800 m and Chilime 1,400 m. The aspect of the villages also varies between windward and leeward side of the mountain. ${ }^{4}$ Gatlang, Goljung and Chilime respectively face north-east, north and south. Land is either khet - irrigated fertile lowlands where paddy is cultivated - , bari - rain-fed terraced land suitable for growing cereals such as maize, millet, wheat, buckwheat, oat, linseed, potato, leguminous beans and vegetables - or khar-bari - thatch or fallow marginal land fit for trees, shrubs, thatch grasses and agro-forestry. Gatlang has very little khet and more bari or khar-bari land. There are substantial public grazing lands called kharka (range/pasture) at 4,500 m. On average, households in Gatlang have nine months of food self-sufficiency. Parvati Lake, located upstream, provides the village with water for drinking and for operating water mills for grinding. The main crops grown are local maize, black millet, buckwheat and local beans. Potato, barley and beans are grown as cash crops to sell in local markets at Chilime, Saybrubesi, Dunche and even the capital, Kathmandu.

In contrast, Goljung has more khet to produce seasonal paddy. ${ }^{5}$ It has bari land for growing linseed, oats, potato, maize, brown millet and beans. It has very little khar-bari and no kharka. Access to drinking water is the major issue in Gojlung, with the burden falling on women in particular as primary caregivers. Average household food security is only six months. Villagers keep a limited number of cattle, buffalo, sheep, goats and chickens. There are fewer transhumance activities.

Chilime, at the bottom of the valley, has fertile khet land in the lower part and bari land in the upper part of the village, where millet, oats, potato and 
maize are grown. Lower Chilime is characterized by rapid urbanization. There are more hotels, lodges, business, trade and shopping facilities, as it has become the market centre for half a dozen new electricity plants along the Sanjen river. Schools, hospitals, banks and agri-collection centres as well as government offices are located here. Hence people have easy access to healthcare, agriculture, forestry, livestock and other relevant services.

Since farming alone is not enough, livestock also contributes to food security. Most of the grazing of cattle, yak and chauris ${ }^{6}$ is transhumant. Among young people there is a growing trend towards alternative livelihoods due to the hardship associated with farming. Households with at least one family member (mostly men) working outside the village are 45 per cent, 80 per cent and 85 per cent in Gatlang, Goljung and Chilime respectively. Young people, especially men, also work on a seasonal basis as guides and porters in the nearby national park and the Tamang heritage trail. ${ }^{7}$ Tourism is promoted and visitors, especially to Gatlang, have increased. Furthermore, the upper Rasuwa area has potential for hydro-electricity generation. In 2017, 16 hydropower projects were under construction in the district, generating employment opportunities for men and some literate women. It has also created economic opportunities: for example, 10 per cent of the equity in the $22 \mathrm{MW}$ Chilime hydropower project is held by locals, including people in the three villages. ${ }^{8}$

\section{Conceptualizing gendered vulnerabilities}

Gender is considered here as a process by which various social attributes associated with being women and men shape the differential responses of groups to stressors, including climatic ones (Harding 1986). Socio-culturally constructed gender relations, roles and responsibilities determine differential access to, ownership of and control over resources for women and men across social groups and influence the ways they adapt to climate change (cf. Harding 1986; Goodrich et al. 2017). These resources may be social, human, economic, physical, financial or technological. We apply a sustainable livelihood framework to analyze various livelihood resources, taking heterogeneities and intersectionalities within a specific group into account while understanding gender vulnerabilities.

We do not confine our understanding of vulnerability to climate change to extremes like flood and landslides. Rather, we consider the impact of climate change on people's lives as a gradual onset of climatic stresses such as increase in temperature, decline in snowfall, erratic rainfall, and a gradual increase of the stresses caused by too much or too little water. Hence vulnerability is assessed in response to gradual processes of climatic stress, as well as climatic extremes and hazards like landslides, floods and droughts, including cataclysmic events such as the earthquakes of 26 April and 12 May 2015.

Understanding gender vulnerability is an opportunity to explore how people turn challenges into opportunities. People and communities are 


\section{Deepak Dorje Tamang and Pranita Bhushan Udas}

not just passive victims, but also active managers of vulnerability (IPCC 2014; Gilson 2013). Hence, integrated and multidimensional approaches are applied to identify its drivers and causes. Our study examines gendered vulnerabilities as the interplay of external factors with the existing internal environment. External factors such as market forces, increasing consumerism, urbanization, globalization, infrastructure development and technological interventions are contrasted with internal geo-political and socio-economic factors of social structure, gender, geography, political economy, decision-making processes and institutions (Goodrich et al. 2019b).

\section{Gender roles and responsibilities}

In this section we analyze gender disparities in roles and responsibilities that lead to differential gender vulnerabilities. The analysis is organized according to the major traditional and newly emerging livelihood strategies.

\section{Transhumance herding, livestock and farming}

Over the last three decades, transhumant herding complemented agriculture and was the over-arching livelihood strategy. However, the life of a herder is challenging.

A transhumant herder ascends to the pastures (kharka) from the settlement in April and descends by September every year. It takes him a fortnight to reach the meadows along with his septuagenarian father and 55 animals. His mother treks up every month to supply them with food, medicines, oil, salt, and fodder-grains for the animals. Once in the kharka, a herder wakes up at 3-4 a.m. and grazes the animals until evening. Then he counts and corrals the animals in the camp site and ensures their safety from wolves and snow leopards. Often the animals stray or go missing in sub-zero temperatures. He goes looking for them with his sheep dogs. Often, many are dead. Sometimes, he returns to his rudimentary shelter at midnight. Exhausted, he often eats raw oats with water to appease his hunger. A herder's life is not for the faint-hearted.

Due to the hardships involved and the dwindling supply of grasses, people have started to give up this work. Though the establishment in 1977 of a cheese factory in Gatlang that provided cash income was an incentive to continue herding, it was only recently that more farmers started to get involved in herding. Supplying milk to the cheese factory provides a more consistent income than the risks of farming. There are also government programmes to support herders, such as loans to buy animals.

Gatlang has about 110 Tamang households and Chilime has 80 households of which 60 Tamang and 20 Ghale families are herders. Goljung has just 10 households consisting of two Ghale and eight Tamang families. The Sanjen kharka grassland for herders from Chilime and Gatlang cannot 
accommodate all the goths (temporary caravan settlements comprising 50 animals on average). Water scarcity and competition for grazing lands are the major issues facing herders.

The herders are mostly middle-aged and older men, mostly those unable to migrate for labour work. Among the younger families, the men take the animals and stay in the kharka, while women journey up and down every month to supply food and look after children at home. In households where the men have migrated, both elderly parents go to the kharka. During our field visits, more elderly than younger women were seen in the kharka.

When the men are away in the kharka, the women bear the triple burden of the reproductive and productive work, as well as community management responsibilities. Women must regularly supply food and other necessities to the men in the goth. Households with ageing members are extremely vulnerable.

Negotiations between mother-in-law and daughter-in-law are challenging when women are to join the kharka for a longer period or to supply goods. A daughter-in-law explained, "I do not have good understanding of kharka like my mother-in-law. I take care of my small child. My mother-in-law supports our family members in kharka." The elderly women in the kharka complained, "The new generation is not interested in learning." These older women experience multiple hardships and health issues. One of them said, "I have extreme knee and back pain these days." In general, Nepalese women experience bone-related problems more than men due to lack of sufficient nutrition and rest during pregnancy and after childbirth (Lamichhane 2005). Milk consumption among these women drastically reduced once milk began to be supplied to the cheese factory. An educated young man who works as a tour guide and is actively involved in village institutions highlighted bone problems as an issue for elderly members of herder families, especially women. Previously, an internal barter system for milk and by-products like butter and local cheese provided sufficient nutrition.

Other than animals in transhumant herding, the women are primary caregivers. They are responsible for fodder collection, feeding animals, cleaning sheds, milking and providing traditional first aid to sick animals. The men do the buying and selling of livestock or products like meat, milk, leather/ hides and bones. Women lack cash in hand compared to men. But involvement with small animals at home provides nutritious foods like milk, meat and eggs. Dalit women care for goats and chickens. Dalits cannot afford to buy and rear big animals like cattle.

Timed task allocation analyses reveal that women in farm households perform most of the tasks related to agricultural and livestock management at the household level (Table 6.1).

Our data suggest that women are involved in more daily labour work than men. Another study suggests that in similar conditions, women out-perform men by nearly 3.5 hours a day on average (Shtrii Shakti 2015; Dough Merrey et al. 2018). Women go to bed late and get up early so they can get all their work done (Koirala et al. 2017). 
Table 6.1 Broad task allocation study (TAS) in the case study sites

\begin{tabular}{lll}
\hline & Women & Men \\
\hline Agriculture & Seed selection & Ploughing \\
& Field preparation & Hoeing \\
& Manure preparation & Harvesting \\
Carrying manure & Barter trade \\
Hoeing & Selling \\
Plodding & \\
Seeding & \\
Planting & \\
Weeding & \\
Harvesting & \\
Storing & \\
Food processing & \\
Grinding & \\
Extracting oil & \\
Collecting grass/fodder & Local herding \\
Feeding animals & Transhumance herding \\
Cleaning/maintaining sheds & Managing crossbreeding, \\
Milking & reproduction \\
Making butter/cheese & Culling and meat production \\
Nursing young/sick animals & Buying and selling livestock \\
Preparing/drying manure & Marketing milk, cheese, animal \\
& products \\
\hline
\end{tabular}

Source: Field data, HI-AWARE, ICIMOD, 2017.

For the Dalits, being landless, the role chart is applicable to those who can lease unutilized low-fertility land from Tamang and Ghale households. Many of them are farm labourers. A few women have goats and chickens that provide cash or meat for the family. Dalits who make and repair agricultural tools for Tamangs and Ghales receive $10 \mathrm{~kg}$ of cereals a year for each adult. However, cash payments for new tools at the local markets rate are catching on fast. Neither the kind nor cash contribution is enough to meet the Dalit household's annual food requirements. Some of these women shared that they had experienced domestic violence as a result of economic stress in the family.

In general, women are paid two-thirds of what men get for the same work due to prevalent notions of women being incapable of hard work. Most of the women labourers are Dalits. In jobs like masonry, carpentry or construction, skilled men get four times what women are paid. This lowers the social and economic position of women compared to men. Reciprocal exchange of labour, the norm until 15 years ago, is gradually being replaced by cash payments due to market penetration in the villages, and this is gradually eroding the social ties that used to be a resource for facing hardship in the high mountains. 


\section{Eco-agro tourism, home stay and handicrafts}

With traditional livelihoods no longer sufficing to meet annual household food requirements, many young men are exploring opportunities in tourism. The first is to the nearby Langtang valley mountain treks and Gosaikunda lake trails. The second is within the three study villages, where the Rural Poverty Alleviation Project (2000-2010) promoted the Tamang Heritage Trail, although the 2015 earthquake $^{9}$ halted momentum. The more educated take jobs as guides, whereas strong non-English-speaking men work as porters. As part of the project about 100 Tamang and 20 Ghale women were trained in ecotourism. Fifteen Dalit women received training in vegetable gardening and micro-enterprises. With the support of small grants, some started small enterprises, such as cultivating herbs as cash crops, woollen handicrafts, retail shops and homestays. Keeping a market-driven business going, however, requires the capacity to bear the financial risk and expand the business using social networks. It was mostly Ghale and a few Tamang women who could make use of these opportunities, as Dalit women have limited capacity for risk taking. It was mostly widows with social and financial capital and women financially supported by male migrant family members who could remain in business. These women entrepreneurs hired paid women labourers, mostly Dalits, to look after their livestock and undertake agricultural tasks.

Educated and wealthy Tamang and Ghale families benefited the most from the tourism industry. They invested in house building and renovation and used their contacts in the capital to attract tourists. Tamang and Ghale women also sell their handicrafts, while the men make furniture and houses for home stays.

Not all the villages offer equal opportunities for ecotourism. Of the three villages, Gatlang, which maintained Tamang cultural activities through a traditional institution called the chogo system that promotes social cohesiveness, attracted the most visitors. Gatlang has eight modest small-tomedium homestay lodges. In contrast, Goljung received the fewest visitors as trekkers often bypass it, going straight down to Chilime. A major tourist attraction in Chilime is the hydropower plant dam, which forms an artificial lake of over one square kilometre.

Under the chogo system, or the Council of Elders, five or six members are selected by community consensus to run village affairs relating to natural resources management, social events including births, deaths and marriages, and village development works. The head of the committee is known as Chogo. Traditionally, the scope of the committee included conflicts with neighbouring villages concerning wild animals. Only physically strong men were Chogos as the work required mobility as well as cooperative ability and the skills to handle confrontations. It is a voluntary position, and women can be members, but according to key informants, women rarely volunteer for the role due to their household responsibilities. During the study period, one woman member was observed to be overseeing social 


\section{Deepak Dorje Tamang and Pranita Bhushan Udas}

events. During festivals, villagers give Chogos gifts such as scarves, shawls and cotton turbans in recognition of their services. Since 2015, in recognition of the importance of the role of Chogo in local social governance, the local government has allocated a monthly remuneration of NRs. 6,000 to each member, which has supported continuation of the chogo system in Gatlang. The twice-yearly week-long mani rimdu cultural festival, held during the birthday celebration of Lord Buddha in May and again during harvest festival in August, has given important cultural significance to this village, attracting tourists and creating alternative livelihood opportunities.

\section{Migration, social capital, finance}

Three decades ago, upper Rasuwa was a place isolated from national and global markets. The trek to the capital, Kathmandu, would take a week. This changed after the army built the $160 \mathrm{~km}$ Trisuli-Somdang jeepable 'dirt road' to access the Somdang lead-zinc mines. A highway linking Kathmandu to Rasuwagadi on the Nepal/Tibet border also increased mobility. With road connectivity, mobility increased, especially for young men who moved to cities like Trisuli and Kathmandu for work and study. Substantial out-migration began in 1990 when Nepal adopted neo-liberal policies. It increased during the Maoist-led civil war between 1995 and 2006. The then government introduced liberal passport policies to encourage young people to go abroad for work. Many young people from upper Rasuwa took jobs in the Gulf and South-east Asia to escape from political unrest. ${ }^{10}$ Although it is mostly men who migrated, a few Tamang and Ghale women from Chilime and Goljung also migrated abroad, whereas women from Gatlang mostly went to the nearby villages at Trisuli and up to Kathmandu for work.

The impact of migration in upper Rasuwa is mixed. FGD participants mentioned that of the total number of families from which at least one member migrated abroad for alternative income, only half were able to uplift their socio-economic status, whereas the other half became more vulnerable after migration. The incidence of family breakdown and indebtedness to finance the emigration are high. The men who migrated abroad returned home after at least two years. This affected a Tamang woman from Goljung, who moved to a nearby marketplace at Syphrubesi to run a hotel. Leaders of a mothers' group stated, "After two decades of male migration, there are fewer men in the villages. The social costs of isolation and separation are high. There are incidences of promiscuity and family breakdown. Physical, social and psychological abuse and violence against women has increased. Sometimes, through our group we rehabilitate women from our villages. We often receive refugees such as pregnant women from southern villages too, who have escaped to the north due to shame. We provide them counselling, shelter and even bus tickets to return home." A young Tamang daughter-in-law mentioned, "We are left with managing our household chores, agriculture and livestock rearing. Social and political participation 
are also our duty now. We have no time at our disposal." Another young woman from Goljung whose husband is abroad said, "Gatlang had a huge forest fire five years ago that no one could put off. Landslides, soil degradation, drying of water system have made life hard." Among the migrant families, many men face challenges in new workplaces abroad, while women and older parents remain behind in a degrading environment without the support of young male family members.

None of the Dalit families have opted for foreign labour migration as they lack the financial resources required to pay upfront. Among the Tamang and Ghale, only those families with strong social and financial capital to absorb the initial financial and social cost were able to uplift their status. Families that have male relatives (such as brothers) to support women and the elderly in the day-to-day running of their livelihood activities could add resources after migration. Some of them invested the savings they had made after migration in farming medicinal herbs in Chilime. Others faced increased drudgery and indebtedness, paying huge interest on the loan taken out to send the family member abroad, and even family breakdown, rendering them still more vulnerable.

\section{Trade and other economic activities}

Emerging new development opportunities in the area such as hydropower and market penetration have provided the opportunity to trade in hydropower shares, medicinal herbs, small and medium food shops and local liquor. Involvement in such opportunities varies across groups and genders.

The Chilime hydropower project was the first in Nepal to provide 10 per cent of its shares to local communities as part of benefit sharing with local communities. Villagers from all three villages were eligible for these shares. A maximum of 300 shares could be allocated to one individual, at a share value of Nepali Rupees 100. But those who could not get to the hydropower office or were unavailable as they were in kharka could not buy the shares. The value of a Rs.100 share during the study period was about Rs. 1,650. The shareholders receive annual dividends of 15-20 per cent. Trading these shares is a new opportunity. Educated and politically active Tamang and Ghale men are actively engaged in share trading to build their assets. Many used their shares to repair homes damaged in the 2015 earthquake. Some bought motorbikes. Those who were less knowledgeable about shares sold them cheaply, losing a valuable asset. Among these are uneducated Dalit women and men, older people in the kharka and relatively poor Tamangs. At the household level, it is mostly men who control share dealings for both women and men. A mother of two boys aged 6 and 2 from Goljung relates how despite her higher secondary education, it is her husband from Gatlang who takes the major decisions on trading the hydropower shares. "My husband who travels frequently to Kathmandu carries out the share transactions for both us. I rely on him and accept his 
decisions. I hardly get involved in creating assets through my shares. Asset creation for Tamang, Ghale and Dalit women are from parental wedding gifts and jewellery bought from savings, and for the fortunate few through remittances and gifts sent by her spouse if he is a conscientious and loyal person."

Women are involved in the collection and processing of medicinal and aromatic herbs found in the forests. About 30 women in Gatlang, 55 women in Tetangche, Chilime and 50 women in Gonggang, Chilime from the Tamang community have formed cooperatives. They cultivate and process herbs as micro-enterprises. The trade in herbs supplements household income. A young woman said, "Forests are like our parents. We revere and worship them. We get resources to meet our social, economic and environmental needs. We worship forests as our mother on Janai Purnima, a full moon day in mid-August. The lake above the three villages is called the Ama Chedingmo, meaning 'our mother' in our language." ${ }^{11}$ The forests surrounding the lake provide plants with medicinal value. Women used some of the plants for household consumption and others were bartered or sold to middlemen of ayurvedic companies. However, in summer 2012 the Gatlang forest was almost completely destroyed by a fire that raged for months.

The Tamang women of the three villages and the Ghale women of Goljung and Chilime bazaar run shops to sell groceries, medicines, stationery, beauty products and other household necessities. There are 12 such shops in Gatlang, five in Goljung and 30 in Chilime. The daily turnover of these shops ranges from NRs. 500 to NRs. 5,000. Due to its strategic location, the Chilime bazaar vendors enjoy the best business. The Dalits are mostly consumers and have not been able to gain much from these new market opportunities. Both Dalit men and women are engaged in the labour market to ensure food security.

There are small and medium businesses that sell cement, sand, stones, steel rods, corrugated iron sheets, paint, wood, bricks and hardware accessories. Some Tamang and Ghale traders supply seeds and fertilizer to the villagers. They harvest and sell potatoes, leguminous beans and medicinal plants on a large scale. There are two such traders in Gatlang, one in Goljung and five in the Chilime bazaar. Their monthly turnover ranges from NRs. 100,000 to NRs. $1,000,000$. The men are in charge of the business while women are looking after the family.

Every Tamang and Ghale household brews raksi a distilled liquor and chaang, beer from millet, maize, wheat and rice. All adult women, except the Dalits, know how to brew liquor. Local alcohol is consumed daily in the household for hospitality and to meet spiritual needs. Women barter or sell it within the village to earn money to pay for children's education and to meet daily household needs. Sometimes savings from liquor sales are used by the women to buy jewellery and clothes. This economic activity is not only an essential part of life for the Tamang and Ghale women but an intrinsic part of the culture of the community. 


\section{Saving and credit activities}

Facilitated by government and non-government agencies, women's saving and credit groups have been promoted in all three villages over the last 10 to 15 years. Previously a few wealthy landlords would lend the money needed for business, agriculture, livestock and daily subsistence at exorbitant interest rates, ranging from 60 to 100 per cent. The women in the saving and credit groups meet once a month to review turnover, cash flow and balance sheet. The amount loaned and the interest rate depends on the balance available and the type of business proposed by the women members. Each borrower has to pay 3 per cent interest a month, or 36 per cent annually, a higher rate than the local banks which charge 18 per cent. However, accessing loans from local banks is a complicated process for women as many of them have no collateral, so it is easier to approach the women's saving and credit group. Moreover, travelling to the bank is expensive for some. Whereas women entrepreneurs at Chilime with large investments can access bank loans, most of the middle-class women used loans from the women's group to buy seeds, fertilizer, agricultural inputs, livestock or poultry, or to construct simple greenhouses for vegetable and herb growing and drip-irrigation systems. Others used the loan to meet social needs, including children's school fees and stationery, medicines or emergencies like death or accidents. One of the women members added, "It is the women who come forward to borrow for the household requirements and often act as proxies to obtain loans for men's needs too." It is mostly middle class Tamangs and Ghales who benefit from these group savings systems. Many Dalit women fail to access such opportunities.

\section{Gendered vulnerabilities, capabilities and adaptation}

Among Tamang, Ghale and Dalit social groups in the study villages, those who lack physical, financial, human, natural and social capital are the most vulnerable. The Dalits are the lowest ranking. After them come marginal Tamang and Ghale, including widows without brothers or male cousins. They tend to be the most vulnerable to climatic stressors. In Goljung, which lacks drinking water, women in this category bear the extra climatic stress burden of managing water for the family. Among the Tamang and Ghale, older people involved in transhumant herding are equally vulnerable to climatic stressors due to their age, health issues and the hardship involved in these activities. In terms of geography, women from poor household in Gatlang and the mountainous part of Chilime are more vulnerable to climatic stressors than those in Goljung considering that new irrigation will increase productivity and Chilime bazar is located in the valley bottom where there is industrial growth and emerging businesses.

The deeply ingrained psychology of 'untouchability' and class discrimination makes Dalits vulnerable in this society even though the villages are 
dominated mainly by Buddhist Tamang and Ghale. Some poor Tamang and Ghale people, as well as Dalits, find day-to-day subsistence living hard to manage. As a coping strategy, many Dalits and marginal Tamang and Ghale have changed their religion to Christianity, as a number of evangelical Christian and faith-based Protestant churches have sprung up in all three villages in the past two decades. According to a key informant in Gatlang, "There are at least three churches in Gatlang and one each in Goljung and Chilime. I estimate that 10 per cent of the Tamang and Ghale population and almost all Dalits have embraced Christianity. This is due to more empathy, basic education and economic help forthcoming from the church groups to these households."

Among migrant Tamang and Ghale people, those who were able to increase their human and financial capital by working abroad can invest in new ventures like large-scale medicinal herb farming. There are few such families in Chilime, so the results are yet to be observed. It is possible that these large-scale enterprises will help to absorb the climatic stress on livelihoods by creating employment opportunities for other subsistence farmers. In contrast, those who lost both financial and social capital through working abroad have become more vulnerable, with women and men sharing an equal burden. Government intervention to create safety nets for families attempting to work abroad could avoid this increase in vulnerabilities. These measures would include monitoring agencies that supply human resources abroad, providing modest loans to support the processing cost; making both women and men aware of the pros and cons of foreign labour migration would help families to make informed decisions.

The process of building social capital through established community life and social mores among Tamang and Ghale, especially among the middle class, has helped to absorb the shock of various stressors, including climatic ones. Spiritual and cultural practices that promote kinship relations can provide immediate support. These practices include: ethics; a code of conduct and moral behaviour called rimthim; respect for the elderly; honouring guests (salgar); traditional self-help and barter system (aicho paicho); mutual labour exchange (parma); shamanism (dhami/jhakri) as faith healing and traditional medicine; festivals such as Losar (New Year) in January/February; festive celebrations and community carnival (mani rimdu) in May/August; and the institution of local Lama and Buddhist monasteries. In Gatlang, households' contributions for festivals are equitably shared, based on income. Maintaining the traditional practice of chogo in Gatlang while merging it with statutory institutions has created a harmonious continuation of traditional institutions while working with the state government. This has led to expansion of tourism in Gatlang and opportunities to diversify livelihoods. Well-informed women are taking advantage of these opportunities to become involved in handicraft micro-enterprises and running homestay lodges. 


\section{Conclusion}

This chapter has shown that there are gender differences in role allocation, access to and control over resources, and dependency relations in Tamang, Ghale and Dalit communities. Women contribute significantly as farm labourers, whereas financial work is done by men. Women are paid twothirds of men's wages. For work outside the home, women are dependent on men. Living in a fragile environment, social capital has a high value and women are highly dependent on men for it. The reciprocal effect of this relationship is that men's access to and control over most of the livelihood resources and decision making is high. Women's dependence on men and limited mobility, and the low value placed on women's work makes women more vulnerable while responding to stressors than men.

The level of vulnerability and resilience among women differs among different ethnic and caste groups depending on class, age, education level and geographical location. Women from the Dalit caste group, who are the lowest in the social hierarchy and have limited livelihood resources, bear multiple burdens of climatic stressors. Among Tamang and Ghale, elderly women are more vulnerable while supporting transhumance herding in harsh environments. The vulnerability of women in Tamang and Ghale households where men have migrated is high among economically poor households with low education levels and limited social networks.

The emerging opportunities in tourism were also found in the study to be differently used by women due to their differing abilities to bear risk and opportunities. Educated and economically stable Tamang and Ghale women are involved in enterprises that have helped to absorb the climatic shocks affecting farming-dependent livelihoods. Women in Goljung managing water for the family bear additional climatic stress burdens, while urbanization has provided some women in Chilime with more entrepreneurship opportunities than in the other two villages.

Policies and programmes that offer adaptation solutions to address vulnerabilities need to recognize the fact that within caste, ethnic and gender groups there are different ways of responding to stressors depending on individuals' levels of access to and control over resources, and their associated capabilities. Initiatives aimed at addressing climate vulnerabilities need to address vulnerabilities caused by intersectional issues of social, financial, economic, political and physical resources. These initiatives may be: interventions to support access to drinking water, irrigation facilities or rural technology for agricultural and livestock rearing; sustainable soil fertility; forest and environmental protection; conservation of biological diversity; improved agriculture and livestock breed management; improvement of rangelands and improved animal breeds; introduction of horticulture for high-value fruits, nuts and medicinal plants; or non-farm sectors like eco-tourism, hydropower share trading, migration and employment generation. 


\section{Deepak Dorje Tamang and Pranita Bhushan Udas}

\section{Notes}

1 Nepal was previously divided into five development regions, 14 geographical zones and 75 districts spread over three ecological regions of mountains, hills and plains called the Tarai. The districts had more than 4,000 villages with the Village Development Committee (VDC) as the lowest political and administrative unit. This demarcation was changed in early 2018 in the spirit of the Constitution of Nepal, 2015. Following this change, the country consists of five development regions, 14 zones, seven provinces from east to west with 713 rural and urban municipalities including five metropolitan cities, and 77 districts. (Nepal Gazette 2018).

2 See https://hi-aware.org/

3 Under the Federal Republic of Nepal's latest political configurations, these three villages have been subsumed and amalgamated into one rural municipality called Ama Chidingmo.

4 In meteorology, leeward and windward are technical terms for the directional sides of a mountain. The windward side is the side which faces the prevailing wind (upwind), whereas the leeward or lee side is the side sheltered from the wind by the elevation of the mountain itself (downwind) (Tiffany, 2018).

5 There was a government-supported irrigation facility that failed to function after construction. Following repairs it started to function in 2017 but the outcome of the system is yet to be observed.

6 A cross between a male yak (Bosgrunniens) and a cow (Bosindicus) is called a chauri. Chauri is a hybrid female which produces more milk and is preferred. The male from this cross is called a jopo (djo) and the chauri is called a diimo. The jopo is not fertile. There are many variations of hybridization of yak and cattle, but the most popular is the chauri among the transhumance herders of Rasuwa.

7 See https://thehimalayantimes.com/business/tamang-heritage-trail-reopened/

8 See http://www.chilime.com.np/images/supportive_docs/Annual-Report-10-11. pdf

9 See http://seismonepal.gov.np/strong-motion

10 The mid-2019 figures for labour migration from Nepal stood at 8 million young people, 90 per cent of them men. Source: South Asian Regional Trade Union Council, Kathmandu

11 The term Adivasi Janajati or 'original settlers' is a term given to over 100 TibetoBurman caste groups to distinguish them from the Indo-Aryan Brahmin/Chhetri and Dalit groups. The former group constitutes 58 per cent and the latter three around 42 per cent of Nepal's 30 million people. The Tamang and Ghale belong to the Adivasi Janajati group (Nepal Gazette 2018).

\section{References}

Campbell, B. 2017. 'Encountering climate change: Dialogues of human and nonhuman relationships within tamang moral ecology and climate policy discourses', European Bulletin of Himalayan Research, 49: 59-87.

Campbell, B. 1997. 'The heavy loads of Tamang identity.' In David N. Gellner, Joanna Pfaff-Czarnecka and John Welpton (eds) Nationalism and Ethnicity in a Hindu Kingdom. The Politics of Culture in Contemporary Nepal. Abingdon: Routledge: 205-236.

CBS. 2013. Summary of National Agriculture Census 2011 AD (2068BS), 2013. Kathmandu: Central Bureau of Statistics. 
Dandekhya, S., England, M., Ghate, R., Goodrich, C.G., Nepal, S., Prakash, A., Shrestha, A., Singh, S., Shrestha, M.S., Udas, P.B. 2017. 'The Gandaki Basin: Maintaining Livelihoods in the Face of Landslides, Floods, and Drought.' HI-AWARE working paper 9. Kathmandu: ICIMOD.

Gerlitz, J.Y., Hoermann, B., and Hunzai, K. 2011. 'Understanding Mountain Poverty in the Hindu Kush-Himalayas: Regional Report for Afghanistan, Bangladesh, Bhutan, China, India, Myanmar, Nepal, and Pakistan.' Case Study. Kathmandu: IFAD.

Gilson, E. 2013. The Ethics of Vulnerability: A Feminist Analysis of Social Life and Practice. New York: Routledge.

Goodrich, C.G., Mehta, M., and Bist, S. 2017. 'Status of Gender, Vulnerabilities and Adaptation to Climate Change in Hindu Kush Himalaya: Impacts and Implications for Livelihoods and Sustainable Mountain Development.' ICIMOD Working Paper 2017/3, International Centre for Integrated Mountain Development, Kathmandu.

Goodrich, C.G., Prakash, A., and Udas, P.B. 2019a. 'Gendered vulnerability and adaptation in Hindu-Kush Himalayas: Research insights', Environmental Development, 31: 1-8.

Goodrich, C.G., Udas, P.B., and Larrington-Spencer, H. 2019b. 'Conceptualizing gendered vulnerability to climate change in the Hindu Kush Himalaya: Contextual conditions and drivers of change', Environmental Development, 31: 9-18.

Gurung, D.R., Maharjan, S.B., Shrestha, A.B., Shrestha, M.S., Bajracharya, S.R., and Murthy, M.S.R. 2017. 'Climate and topographic controls on snow cover dynamics in the Hindu Kush Himalaya', International Journal of Climatology, 37: 3873-3882.

Harding, S. 1986. The Science Question in Feminism. Ithaca, USA and London, UK: Cornell University Press.

HI-AWARE. 2017. 'Socio-economic Assessment Report - Gandaki River Basin, Nepal.' Himalayan Water and Resilience Research (HI-AWARE) International Centre for Integrated Mountain Development (ICIMOD), unpublished report.

Humagain, K., and Shrestha, K.K. 2009. 'Medicinal plants in Rasuwa district, central Nepal: trade and livelihood', Botanica Orientalis: Journal of Plant Science, 6: 39-46.

IPCC. 2014. 'Climate Change 2014: Synthesis Report. Contribution of Working Groups I, II and III to the Fifth Assessment Report of the Intergovernmental Panel on Climate Change' (Core Writing Team, R.K. Pachauri and L.A. Meyer (eds). Geneva: IPCC: 151.

Khan, A., Cundill Kemp, G., Currie-Alder, B., and Leone, M. 2018. 'Responding to Uneven Vulnerabilities: A Synthesis of Emerging Insights from Climate Change Hotspots'. CARIAA Working Paper no. 22. International Development Research Centre, Ottawa, Canada and UK Aid, London, United Kingdom. Available online at: https://idl-bnc-idrc.dspacedirect.org/handle/10625/56958

Koirala, M., Udas, P.B., and Goodrich, C.G. 2017. 'Gender and social inclusion in environmental discourse'. In D. R. Bhuju, M. Koirala and R. Nakarmi (eds), Environmental Science-Some Theoretical Background and Applications. Kathmandu: Central Department of Environmental Science, Tribhuvan University and International Centre for Integrated Mountain Development.

Lamichhane, A.P. 2005. 'Osteoporosis-an update'. Journal of the Nepal Medical Association, 44(158): 60-66. 


\section{Deepak Dorje Tamang and Pranita Bhushan Udas}

Merrey, D.J., Hussain, A., Tamang, D.D., Thapa, B., and Prakash, A. 2018. 'Evolving high altitude livelihoods and climate change: A study from Rasuwa District, Nepal', Food Security, 10(4):1055-1071.

Nepal Gazette. 2018. Department of Printing, Ministry of Information and Communication, Government of Nepal

Pasteur, K. 2011. From Vulnerability to Resilience: A Framework for Analysis and Action to Build Community Resilience. Rugby: Practical Action Publishing.

Pradhan, R., and Shrestha, A. 2005. Ethnic and Caste Diversity: Implications for Development. Kathmandu: Asian Development Bank, Nepal Resident Mission.

Sharma, E., Molden, D., Rahman, A., Khatiwada, Y.R., Zhang, L., Singh, S.P., Yao, T., Wester, P. 2019. 'Introduction to the Hindu Kush Himalaya Assessment.' In P. Wester, A. Mishra, A. Mukherji, A.B. Shrestha. (eds) The Hindu Kush Himalaya Assessment: Mountains, Climate Change, Sustainability and People. Berlin and Cham: Springer.

Shtrii Shakti. 2015. Revisiting the Status of Women in Nepal. Kathmandu: Shtrii Shakti.

Tamang, M.S., and Gurung, O. 2014. Social Inclusion Atlas of Nepal, Ethnic and Caste Groups (Vol.1). Central Department of Sociology/Anthropology, Tribhuvan University, Kathmandu, Nepal. 